\title{
Nodal Morphogens
}

\author{
Alexander F. Schier \\ Department of Molecular and Cellular Biology, Harvard Stem Cell Institute, Center for Brain Science, Broad \\ Institute, Harvard University, 16 Divinity Avenue, Cambridge, Massachusetts 02138 \\ Correspondence: schier@mcb.harvard.edu
}

Nodal signals belong to the TGF- $\beta$ superfamily and are essential for the induction of mesoderm and endoderm and the determination of the left-right axis. Nodal signals can act as morphogens - they have concentration-dependent effects and can act at a distance from their source of production. Nodal and its feedback inhibitor Lefty form an activator/inhibitor pair that behaves similarly to postulated reaction-diffusion models of tissue patterning. Nodal morphogen activity is also regulated by microRNAs, convertases, TGF- $\beta$ signals, coreceptors, and trafficking factors. This article describes how Nodal morphogens pattern embryonic fields and discusses how Nodal morphogen signaling is modulated.

In his 1901 book "Regeneration," Thomas Hunt Morgan speculated that "if we suppose the materials or structures that are characteristic of the vegetative half are gradually distributed from the vegetative to the animal half in decreasing amounts, then any piece of the egg will contain more of these things at one pole than the other" and "gastrulation depends on the relative amounts of the materials in the different parts of the blastula" (Morgan 1901). Although Morgan's speculations referred to the sea urchin embryo, they foretold our current understanding of morphogen gradients in frog and fish development. Morgan's "materials," "structures," and "things" are the Nodal signals that create a vegetal-to-animal activity gradient to regulate germ layer formation and patterning. This article discusses how Nodal signaling provides positional information to fields of cells. I first portray the components of the signaling pathway and describe the role of Nodal signals in mesendoderm induction and leftright axis specification. I then discuss how Nodal morphogen gradients are thought to be generated, modulated, and interpreted.

\section{THE NODAL SIGNALING PATHWAY}

Like most TGF- $\beta$ signals, Nodal ligands activate serine/threonine kinase receptors that phosphorylate Smad proteins to regulate gene expression (reviewed in Schier 2003; Shen 2007; Wu and Hill 2009). In the case of Nodal, the signal is received by type I and II Activin receptors and EGF-CFC coreceptors. Receptor activation results in the phosphorylation of the transcription factors Smad2 and Smad3. This leads to their binding to Smad4, nuclear translocation, and association with additional transcription factors to regulate target genes. Several extracellular proteins, including processing enzymes and antagonists, regulate this

Editors: James Briscoe, Peter Lawrence, and Jean-Paul Vincent

Additional Perspectives on Generation and Interpretation of Morphogen Gradients available at www.cshperspectives.org

Copyright (C) 2009 Cold Spring Harbor Laboratory Press; all rights reserved; doi: 10.1101/cshperspect.a003459

Cite this article as Cold Spring Harb Perspect Biol 2009;1:a003459 


\section{A.F. Schier}

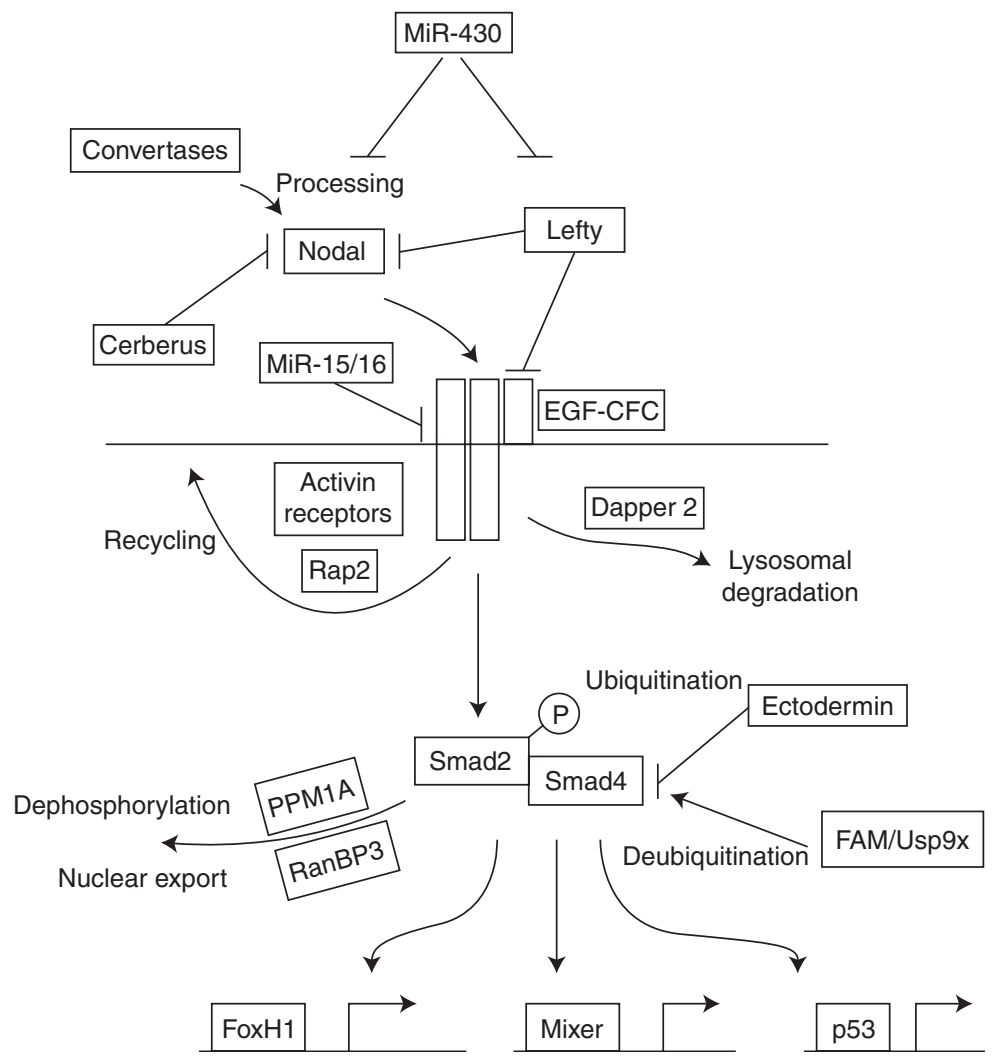

Figure 1. The Nodal signaling pathway. After processing of the Nodal precursor by convertases, Nodal ligands signal through activin receptors and EGF-CFC coreceptors. Cerberus and Lefty act as extracellular inhibitors. MicroRNAs belonging to the miR-430 family target Nodal (zebrafish squint) and Lefty mRNAs for degradation and repression. Mir-15/16 represses the type II activin receptor. Rap2 is involved in the recycling of activin receptors whereas Dapper 2 targets activin receptor complexes for degradation in the lysosome. Pathway activation is mediated by phosphorylation of Smad2 and its association with Smad4 and transcription factors such as FoxH1, Mixer, and p53. Phospho-Smad2 is dephosphorylated by PPM1A and exported from the nucleus by RanBP3. Smad4 activity and stability is regulated by the ubiquitinase Ectodermin and the deubiquitinase FAM/Usp9x. See text for details.

core pathway. In addition, intracellular molecules such as transcriptional cofactors, proteins involved in receptor trafficking, and miRNAs regulate Nodal signaling. To understand how Nodal morphogen activity is regulated, one first needs to understand the molecular basis of Nodal signal transduction (Fig. 1).

\section{Nodal Signals, Convertases, and} Extracellular Antagonists

TGF- $\beta$ signals belonging to the Nodal subfamily were initially found in chordates but were notably absent from Ecdysozoa such as
Drosophila or Caenorhabditis elegans. They are now also known to be present in deuterostomes (e.g., sea urchin) and in the protostome group of Lophotrochozoa (e.g., snails) where, similar to chordates, they control left-right asymmetry and chirality (Duboc et al. 2004; Chea et al. 2005; Grande and Patel 2009). The absence of Nodal in Drosophila or C. elegans might reflect the different, more derived modes of mesendoderm and left-right specification in these systems. Although there is only one Nodal gene in mouse (Zhou et al. 1993), there are three in zebrafish (Cyclops, Squint, and Southpaw) (Erter et al. 1998; Feldman et al. 
1998; Rebagliati et al. 1998a; Rebagliati et al. 1998b; Sampath et al. 1998; Long et al. 2003) and five in Xenopus (Xnr1, 2, 4, 5, and 6) (Jones et al. 1995; Joseph and Melton 1997; Takahashi et al. 2000).

Nodal proteins are translated as proproteins, consisting of a prodomain and a mature ligand domain. Studies in mouse have shown that the convertases Spc1 and Spc4 (also known as Furin and Pace4, respectively) cleave Nodal precursors at R-X-(K/R/X)-R consensus sequences (Beck et al. 2002). The Nodal precursor can be secreted and processed extracellularly by Spc1 and Spc4. Processing is essential for activation of the Nodal signaling pathway in zebrafish and mouse embryonic tissues (Beck et al. 2002; Le Good et al. 2005), but a nonprocessable Nodal precursor can activate the pathway in mouse extraembryonic ectoderm (Ben-Haim et al. 2006).

Additional signaling complexity is introduced by the finding that several related TGF- $\beta$ ligands act through the same pathway as Nodal. For example, mouse GDF1 and GDF3, and the related frog and zebrafish Vg1, activate the pathway via Activin receptors and EGF-CFC coreceptors (Thomsen and Melton 1993; Cheng et al. 2003; Chen et al. 2006; Andersson et al. 2007; Karkera et al. 2007). Double mutant analysis has shown that Nodal can have both overlapping and nonredundant roles with GDF1. GDF1 and Nodal are both required for left-right specification, suggesting interdependent or synergistic roles (Rankin et al. 2000; Andersson et al. 2006). Indeed, GDF1 can heterodimerize with Nodal to generate a more active ligand than the corresponding homodimers (Tanaka et al. 2007).

Extracellular inhibitors such as Lefty and Cerberus antagonize Nodal signaling. Leftys are divergent members of the TGF- $\beta$ family and block Nodal signaling by binding to Nodal itself and to EGF-CFC coreceptors (Meno et al. 1996; Bisgrove et al. 1999; Meno et al. 1999; Thisse and Thisse 1999; Thisse et al. 2000; Agathon et al. 2001; Chen and Schier 2002; Chen and Shen 2004; Cheng et al. 2004). Cerberus and Cerberus-like proteins like Charon bind directly to Nodal, inhibit its binding to receptors, and thus regulate embryonic patterning (Bouwmeester et al. 1996; Piccolo et al. 1999; Bertocchini and Stern 2002; Silva et al. 2003; Hashimoto et al. 2004; Marques et al. 2004; Yamamoto et al. 2004; Tavares et al. 2007; Belo et al. 2008). Loss of Lefty antagonists results in ectopic and prolonged activity of Nodal signaling, leading to ectopic mesendoderm formation and abnormal left-right patterning (Meno et al. 1998; Meno et al. 1999; Agathon et al. 2001; Meno et al. 2001; Chen and Schier 2002; Feldman et al. 2002; Yamamoto et al. 2004).

\section{Receptors and Signal Transducers}

Nodal signals assemble receptor complexes consisting of type I and type II activin receptors (ActRIB; ActRIIA/B) that function as serine/ threonine kinases (Reissmann et al. 2001; Yeo and Whitman 2001; Yan et al. 2002). Assembly results in the phosphorylation and activation of the type I receptor by the type II receptor. EGF-CFC proteins are extracellular GPI-linked factors that are required for Nodal signaling and embryogenesis (Schier et al. 1997; Shen et al. 1997; Ding et al. 1998; Zhang et al. 1998; Gritsman et al. 1999; Yan et al. 1999; Bamford et al. 2000; Shen and Schier 2000; de la Cruz et al. 2002; Dorey and Hill 2006; Onuma et al. 2006). For example, absence of the EGF-CFC protein one-eyed pinhead inactivates the pathway and renders embryos resistant to Nodal (Gritsman et al. 1999). It is thought that EGF-CFC proteins act as coreceptors by binding to Nodal and the type I activin receptor (Reissmann et al. 2001; Yeo and Whitman 2001; Yan et al. 2002; Cheng et al. 2003; Cheng et al. 2004; Chu et al. 2005; Minchiotti 2005).

Recent tissue culture studies have highlighted the importance of ligand and receptor trafficking in Nodal signaling. For example, the mammalian EGF-CFC protein Cripto can promote Nodal signaling by linking the processing and trafficking of Nodal (Constam 2009). Cripto forms a complex with Nodal precursors and convertases at the surface of responding cells and facilitates Nodal processing and translocation to early endosomes 


\section{A.F. Schier}

(Blanchet et al. 2008a; Blanchet et al. 2008b). Moreover, on internalization, Cripto facilitates the interaction with Activin receptors by attenuating the sorting of Nodal into intraluminal vesicles that are destined for lysosomal degradation (Blanchet et al. 2008b). Although the in vivo relevance of these findings remains to be tested, they suggest important roles of trafficking during Nodal signaling. Indeed, previous studies have shown that receptor trafficking plays an important role in TGF- $\beta$ signaling. Receptors can either be recycled or targeted for degradation depending on the trafficking route (Constam 2009). Signaling is thought to occur in endosomes generated by clathrinmediated internalization, whereas degradation is thought to be mediated by a lipid-raft/caveolar internalization pathway and trafficking to lysosomes (Di Guglielmo et al. 2003). It remains to be determined whether this model applies to Nodal signaling. For example, the degradative uptake of Nodal does not involve caveolin-positive carriers in tissue culture (Blanchet et al. 2008b), and signaling is mediated by interaction with EGF-CFC proteins localized to flotillin-positive lipid rafts (Blanchet et al. 2008b). It is clear, however, that the regulation of Activin receptor trafficking can modulate signaling (Jullien and Gurdon 2005). The Ras GTPase Rap2 promotes recycling of nonbound Activin Receptors and delays degradation of ligand-receptor complexes and thus up-regulates signaling (Choi et al. 2008). In contrast, Dapper 2 is induced by Nodal signaling and recruited to late endosomes where it binds the type I activin receptor and enhances the lysosomal degradation of Nodal receptors (Zhang et al. 2004). In addition, subunits of the PP2A phosphatase influence activin receptor levels and signaling (Batut et al. 2008). These studies indicate that ligand and receptor trafficking and stability have important roles in regulating the strength and duration of Nodal signaling.

\section{Transcription Factors and Target Genes}

Nodal receptor activation results in phosphorylation of Smad2/3 and association with
Smad4 and other transcription factors (Massague et al. 2005; Ross and Hill 2008). These activated Smad complexes accumulate in the nucleus as a result of decreased export rate and increased import rate compared with monomeric unphosphorylated Smads. Smads shuttle between nucleus and cytoplasm and thus can continuously monitor and respond to receptor activity (Bourillot et al. 2002; Inman et al. 2002; Xu et al. 2002; Nicolas et al. 2004; Schmierer and Hill 2005; Schmierer et al. 2008).

Smad4 mutant phenotypes are less severe than Smad2/3 mutant phenotypes, indicating Smad4-independent gene regulation by Nodal (Chu et al. 2005). Moreover, Smad3/4 have relatively poor affinity for DNA, whereas Smad2 has no DNA binding activity. Thus, Smad proteins must form complexes with specific transcription factors to recognize and regulate Nodalresponsive cis-elements (Massague et al. 2005; Ross and Hill 2008). Proteins such as FoxH1, Mixer, and p53 form complexes with Smad proteins and contribute to the specific recognition and regulation of subsets of Nodal target genes (Chen et al. 1996; Germain et al. 2000; Hoodless et al. 2001; Yamamoto et al. 2001; Hart et al. 2002; Cordenonsi et al. 2003; Takebayashi-Suzuki et al. 2003). For example, loss of FoxH1 or Mixer leads to distinct phenotypes in zebrafish (Kikuchi et al. 2000; Pogoda et al. 2000; Sirotkin et al. 2000), whereas FoxH1; Mixer double mutants show more than additive phenotypes (Kunwar et al. 2003). These results have led to the model that $\operatorname{Smad} 2 / 3 / 4$ cofactors regulate distinct but partially overlapping sets of Nodal downstream genes (Ross and Hill 2008).

The activity of Smad complexes is regulated post-translationally (Lin et al. 2006; Episkopou et al. 2001; Niederlander et al. 2001; Iratni et al. 2002; Dupont et al. 2005; Cordenonsi et al. 2007; Levy et al. 2007; Mavrakis et al. 2007; Nagano et al. 2007; Yun et al. 2007; Sasai et al. 2008; Dai et al. 2009; Dupont et al. 2009). $\operatorname{Smad} 2 / 3$ is activated by receptor-mediated phosphorylation and inhibited by phosphatases such as PPM1A (Lin et al. 2006). Dephosphorylated Smad $2 / 3$ is then recognized 
by RanBP3 and exported from the nucleus (Dai et al. 2009). Interference with PPM1A or RanBP3 activity leads to an increase of TGF- $\beta$ signaling. Additionally, ubiquitination and de-ubiquitination of Smad4 contribute to Nodal signaling. Smad4 monoubiquitination by Ectodermin lowers pathway activity, whereas de-ubiquitination by FAM/Usp9x allows interaction with P-Smad2 and pathway activation (Dupont et al. 2005; Dupont et al. 2009). In contrast, the ubiquitin ligase Arkadia increases pathway activity, but its exact mechanism of action is controversial (Episkopou et al. 2001; Niederlander et al. 2001; Koinuma et al. 2003; Levy et al. 2007; Mavrakis et al. 2007; Nagano et al. 2007). Cofactor activity is also regulated. For example, Drap1 can bind to FoxH1 and attenuate Nodal signaling, and Serum response factor interacts with Smad2 and FoxH1 to inhibit the formation of Smad2-FoxH1 complexes (Iratni et al. 2002; Yun et al. 2007). The Zn-finger factor XFDL156 binds p53, blocking its interaction with P-Smad2 (Sasai et al. 2008). Conversely, Ras/MAPK signaling promotes $\mathrm{p} 53$ phosphorylation and enhances its interaction with P-Smad2 (Cordenonsi et al. 2007).

A plethora of Nodal target genes have been identified (Dickmeis et al. 2001; Bennett et al. 2007a; Guzman-Ayala et al. 2009). For example, genomic analyses in zebrafish show that Nodal initiates a cascade of regulatory events by inducing the expression of transcription factors and additional signaling molecules (Dickmeis et al. 2001; Bennett et al. 2007a). In addition, Nodal also has direct effects on cell behavior by regulating cytoskeletal components and other differentiation genes. With the exception of Nodal itself, the feedback inhibitor Lefty and the transcription factor pitx2, no downstream genes have been found that are shared between Nodal signaling in mesendoderm and left-right specification in all vertebrates (Adachi et al. 1999; Bisgrove et al. 1999; Norris and Robertson 1999; Osada et al. 2000; Saijoh et al. 2000; Faucourt et al. 2001; Shiratori et al. 2001; Norris et al. 2002; Vincent et al. 2004; Saijoh et al. 2005; Shiratori et al. 2006; Guzman-Ayala et al. 2009). This suggests that although the core Nodal signaling pathway has been conserved across evolution, the downstream targets are divergent between different tissues.

\section{THE ROLES OF NODAL SIGNALS IN DEVELOPMENT}

To discuss how Nodal proteins provide positional information, one first needs to understand how the pathway is used during mesendoderm induction and left-right patterning. For a discussion of Nodal signals in other developmental contexts, see Shen 2007.

\section{Mesendoderm Induction}

The formation of the three germ layers-endoderm, mesoderm, and ectoderm - is a prerequisite for the formation of vertebrate organs (Kimelman and Schier 2002; Stern 2004; Schier and Talbot 2005; Solnica-Krezel 2005; Heasman 2006; Tam and Loebel 2007; Arnold and Robertson 2009). Nodal signals are essential for the induction and patterning of mesoderm and endoderm (Conlon et al. 1991; Conlon et al. 1994; Feldman et al. 1998; Gritsman et al. 1999; Agius et al. 2000; Schier and Shen 2000; Brennan et al. 2001; Schier 2003; Bennett et al. 2007b; Shen 2007). For example, in the absence of Nodal signaling, mouse embryos do not form the primitive streak and zebrafish embryos lack all endoderm and head and trunk mesoderm, including notochord, heart, kidney, blood, liver, pancreas, and gut (Conlon et al. 1991; Conlon et al. 1994; Feldman et al. 1998; Gritsman et al. 1999; Bennett et al. 2007b). Nodal signaling is active during blastula stages, when cells are pluripotent. During normal embryogenesis, spatially localized activity of the Nodal pathway induces and patterns mesendoderm at the appropriate position (Fig. 2). Conversely, ectopic activation of the pathway induces ectopic mesendoderm (Jones et al. 1995; Toyama et al. 1995; Schier 2003; Shen 2007). The in vitro differentiation of embryonic stem cells uses this inducing property of Nodal in which activation of Nodal signaling helps to 
A.F. Schier

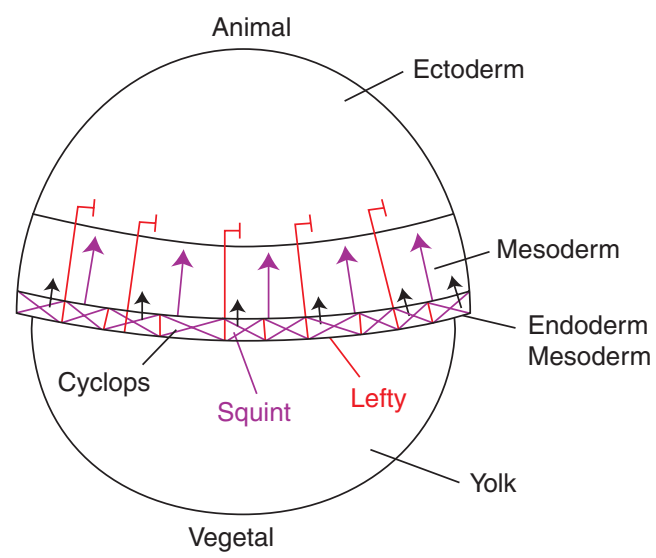

Figure 2. Mesoderm and endoderm induction in zebrafish. Ectoderm, mesoderm, and mesendoderm precursors are arranged from animal to vegetal positions at the blastula stage. The Nodal signals Squint and Cyclops and the inhibitor Lefty are expressed at the blastula margin. Genetic studies suggest that Cyclops has short-range activity whereas Squint and Lefty have long-range activity. See text for details.

maintain the pluripotent state and drive development along the mesendodermal pathway (Parisi et al. 2003; Brandenberger et al. 2004; Kubo et al. 2004; Vallier et al. 2004; D'Amour et al. 2005; James et al. 2005; Pfendler et al. 2005; Vallier et al. 2005; Camus et al. 2006; Takenaga et al. 2007; Smith et al. 2008; Vallier et al. 2009).

Several mechanisms spatially restrict activation of Nodal signaling. In zebrafish and frog, Nodal genes are transcribed in the vegetal region, which overlaps with endoderm precursors and is adjacent to presumptive mesoderm. Thus, local transcription generates a local source of Nodal signals. It appears that high levels of Nodal signaling in and close to the source induce endoderm, whereas lower levels induce mesoderm in neighboring cells (Schier 2003; Schier and Talbot 2005; Shen 2007).

In contrast to the transcriptional restriction of Nodal gene expression in zebrafish and frog, the local activation of mouse Nodal signaling is initially achieved post-transcriptionally. Nodal transcription is initiated throughout the epiblast. Nodal precursor protein produced by the epiblast induces the transcription of the convertases Furin and Pace4 in extraembryonic ectoderm (Ben-Haim et al. 2006). These convertases are secreted and process Nodal in the adjacent epiblast, initiating an autoregulatory feedback that enhances Nodal transcription in a subset of epiblast cells that include mesendoderm precursors (Beck et al. 2002). In addition to the local generation of Nodal mRNA and protein, inhibition of the pathway by extracellular antagonists further restricts mesendoderm formation. For example, loss of the inhibitor Lefty leads to the transformation of presumptive ectoderm into mesendoderm (Meno et al. 1999; Agathon et al. 2001; Chen and Schier 2002; Feldman et al. 2002; PereaGomez et al. 2002).

\section{Left-Right Patterning}

Vertebrate organs are positioned asymmetrically not only along the anterior-posterior and dorsal-ventral axes but also the left-right axis (Shiratori and Hamada 2006). Nodal genes are expressed in the left lateral plate mesoderm and required for left-right axis specification (Levin et al. 1995; Collignon et al. 1996; Lowe et al. 1996; Yan et al. 1999; Lowe et al. 2001; Long et al. 2003; Kumar et al. 2008). Asymmetric activation of the pathway induces asymmetric organ morphogenesis (Yan et al. 1999; Bamford et al. 2000; Concha et al. 2000; Concha et al. 2003; Halpern et al. 2003; Yashiro et al. 2007; Davis et al. 2008; de Campos-Baptista et al. 2008; Kurpios et al. 2008; Bakkers et al. 2009; Roussigne et al. 2009). For example, activation of Nodal signaling in left heart progenitors allows leftward movement and enhances the speed of cardiomyocytes (Baker et al. 2008; de CamposBaptista et al. 2008; Bakkers et al. 2009). In the zebrafish diencephalon, left-sided Nodal expression promotes neurogenesis in the left habenula and the movement of the parapineal organ to the left (Concha et al. 2000; Concha et al. 2003; Halpern et al. 2003; Roussigne et al. 2009). During mouse development, 
Nodal signaling is required for asymmetric organogenesis, ranging from lung lobe formation (Yan et al. 1999) to gut morphogenesis (Davis et al. 2008; Kurpios et al. 2008). In the absence of Nodal signaling, organ asymmetry is lost, randomized, or isomeric.

Nodal expression in the left lateral plate mesoderm is dependent on Nodal expression in cells in or next to the embryonic midline (Fig. 3). For example, mouse Nodal is expressed in the node and induces Nodal in the left lateral plate mesoderm. This process requires intact cilia and fluid flow in the node (Nonaka et al. 1998; Nonaka et al. 2002) and appears to be mediated by the movement of Nodal protein to the lateral plate mesoderm (Brennan et al. 2002; Nonaka et al. 2002; Saijoh et al. 2003; Nakamura et al. 2006; Oki et al. 2007). In contrast to mesendodermal patterning, graded Nodal signaling does not appear to be required for left-right patterning. Thus, Nodal signaling might simply control the binary decision of

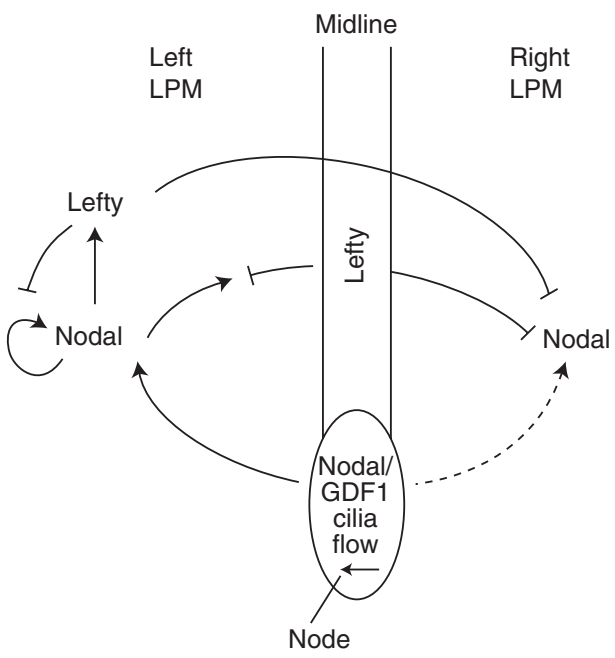

Figure 3. Model for left-right patterning by Nodal and Lefty. Nodal/GDF1 heterodimers form in the region of the node and activate Nodal signaling in the lateral plate mesoderm (LPM). Cilia-induced fluid flow biases Nodal activation toward the left. Subsequent Nodal autoregulation, induction of Lefty expression, and long-range inhibition by Lefty lead to robust pathway activation on the left and inhibition on the right. See text for details. left versus right. However, similar to the restriction of Nodal signaling in mesendoderm development, extracellular antagonists belonging to the Lefty family restrict Nodal signaling to only the left side (Meno et al. 1998; Feldman et al. 2002; Nakamura et al. 2006).

\section{NODAL SIGNALS AS MORPHOGENS}

Nodal signals can act as morphogens-they directly act at a distance from their site of production and induce concentration-dependent responses in target cells.

\section{Direct Long-Range Effects of Nodal Signals}

The range of vertebrate TGF- $\beta$ signals was a contentious issue in the 1990s. It was unclear whether such signals can act directly at a distance or depend on relay signals that indirectly mediate their effects (Gurdon et al. 1994; Jones et al. 1996; Reilly and Melton 1996; McDowell et al. 1997). Studies of Activin revealed long-range effects, whereas studies of TGF- $\beta 1$ suggested short-range activity; however, because the tested ligands are neither expressed in the blastula nor required for normal mesendoderm induction, the in vivo relevance of these experiments was unclear (Schier and Shen 2000). The isolation of Nodal genes allowed the analyses of endogenously expressed and functionally essential TGF- $\beta$ s. This revealed both short- and longrange activity of Nodal signals during mesendoderm induction (Chen and Schier 2001).

In zebrafish, several lines of evidence suggest that the Nodal signals Cyclops and Squint have short- and long-range effects, respectively (Chen and Schier 2001). First, misexpression of Squint from a localized source induces longrange activation of Nodal downstream genes in surrounding tissue, whereas Cyclops only has short-range activity (Fig. 2). Second, in vivo target gene induction in Squint mutants is only short-range and originates from Cyclops. Conversely, Squint-mediated gene induction is still long-range in Cyclops mutants. Third, the long-range effect of Squint appears to be 


\section{A.F. Schier}

direct, because Squint generated in coreceptor mutant (i.e., nonresponding) cells can traverse a field of nonresponsive, coreceptor mutant cells and activate Nodal target genes in distant wild-type cells. These experiments rule out a Squint-induced relay signal and provided evidence that Squint can act directly at a long range. Further support for direct long-range Nodal action during mesendoderm formation has been provided by the distribution of Xenopus Nodal protein Xnr2 (Williams et al. 2004). Local expression of Xnr2-GFP results in the extracellular movement of the fluorescent protein from the source into nonexpressing tissue.

Nodal signals also have long-range activity during left-right specification. For example, mouse Nodal can be generated in nonresponsive coreceptor mutant node cells, traverse nonresponsive mesoderm, and activate Nodal target genes in distant wild-type cells in the LPM (Oki et al. 2007). Similarly, Nodal expression in the LPM is required for expression of leftyl in the midline (Yamamoto et al. 2003). Taken together, these studies clearly establish that Nodal ligands can have direct long-range effects.

\section{Concentration-dependent Effects of Nodal Signals}

Nodal signals can induce dose-dependent effects in responding cells as seen by varying the concentration of Nodal ligands and determining downstream gene expression. Such experiments have revealed at least two thresholds for Nodal-dependent gene activation. For example, low levels of Nodal are sufficient to induce targets such as $\mathrm{ntl} / \mathrm{T} /$ Brachyury and floating head/Xnot, whereas the targets goosecoid and casanova/sox32 are activated only by high levels of Nodal (Gurdon and Bourillot 2001; Schier and Talbot 2005). Further evidence for dose-dependent effects of Nodal signaling comes from mutants that partially decrease Nodal activity. For example, partial reduction of Nodal, Smad2/3, or EGF-CFC coreceptor activity leads to loss of high threshold target gene expression and absence of endoderm and prechordal plate mesoderm (Schier et al. 1997; Gritsman et al. 2000; Thisse et al. 2000; Dougan et al. 2003; Vincent et al. 2003).

Together with the local expression and longrange activity of Nodal ligands, these findings have suggested a model wherein Nodal ligands such as Squint form a concentration gradient from the vegetal to the animal pole, much as T.H. Morgan had predicted (Schier 2003). This gradient provides positional information so that cells acquire fates according to their location in the gradient. A gradient of Nodal signals has not yet been visualized, but an activity gradient can be visualized by the domains of target gene expression, P-smad2 levels, and nuclear accumulation of Smad2fluorescent protein fusions (Faure et al. 2000; Gritsman et al. 2000; Chen and Schier 2001; Lee et al. 2001; Harvey and Smith 2009). For example, zebrafish Smad2 accumulates in a vegetal-to-animal gradient in zebrafish blastula nuclei (Harvey and Smith 2009). These observations support the idea that an activity gradient of Nodal signaling specifies different cell types along the vegetal-animal axis.

\section{Time-dependent Effects of Nodal Signals}

The spatial concentration gradient model is consistent with the gene expression domains of Nodal downstream genes and the blastula fate map, but it has several limitations. First, zebrafish mesendoderm can eventually form normally even in the absence of the long-range signal Squint, i.e., solely by the action of the short-range ligand Cyclops (Feldman et al. 1998; Chen and Schier 2001; Dougan et al. 2003). Second, downstream responses are not only determined by the concentration of the signal at a given time but also the duration of pathway activity. For example, expression of high-threshold targets is absent on premature block of the pathway by receptor inhibitors or loss of coreceptors (Gritsman et al. 2000; Aoki et al. 2002; Hagos and Dougan 2007). A similar loss of high-threshold target gene expression is observed on delayed pathway activation caused by late expression of coreceptors (Gritsman et al. 2000). Moreover, cells 
exposed to a uniform dose of Nodal mRNA progressively move from low- to high-threshold fates with increasing time of exposure (Hagos and Dougan 2007). Analogously, nuclear accumulation of Smad2 increases within a one-hour time window in the late zebrafish blastula (Harvey and Smith 2009). These experiments reveal a clear role for prolonged exposure to Nodal ligands and suggest that the cumulative dose (concentration and time) of Nodal determines the fate of responding cells. The cumulative dose model might also explain why short-range Cyclops can induce all mesendodermal cell types in the absence of long-range Squint. Different times of exposure of blastomeres to Cyclops might allow the differential activation of Nodal signaling and the generation of different cell types.

The duration of Nodal signaling might be measured at several points in the pathway. For example, to elicit a particular response, sufficient ligand has to accumulate over time. Thus, in Squint mutants, induction of cell fates is delayed, whereas overexpression of Nodal ligands can accelerate fate specification (Hagos and Dougan 2007). Timing is also likely to influence events at the receptor level. For example, blocking receptor activity after exposure to high doses of Nodal attenuates the response and leads to absence of high-threshold target gene expression (Hagos and Dougan 2007). This result argues against the idea that a given concentration of Nodal is sufficient to induce a long-lasting response and suggests that cumulative dose is measured at the receptor level or downstream. Indeed, studies on Activin suggest that one mechanism of memory of previous exposure to ligand might be the high stability and residence of signalreceptor complexes in intracellular vesicles after endocytosis and before lysosomal degradation (Dyson and Gurdon 1998; Gurdon and Bourillot 2001; Jullien and Gurdon 2005). Taken together, these studies suggest that the cumulative dose of Nodal signaling determines cells fates. It is unclear, however, how concentration and duration are translated into positional identities (Ashe and Briscoe 2006).
A Reaction-Diffusion System: Mid-range

Activation by Nodal and Long-range

Inhibition by Lefty

The noncanonical TGF- $\beta$ signal Lefty is a potent feedback inhibitor of Nodal signaling (Meno et al. 1999). Several studies have suggested that Nodal and Lefty constitute an activator/inhibitor pair as postulated in reaction-diffusion models of pattern formation (Saijoh et al. 2000; Chen and Schier 2002; Hamada et al. 2002; Schier 2003; Nakamura et al. 2006). In such models, a locally acting activator induces both its own synthesis and the synthesis of a long-range inhibitor (Fig. 4) (Turing 1952; Meinhardt and Gierer 2000). In the classic reaction-diffusion system, such interactions can result in self-organization that generates patterns in an initially homogenous field of cells. Nodal/Lefty share the activator/ inhibitor and self-enhancement features of this system. For example, in the zebrafish blastula, Nodal activates Nodal and Lefty transcription at the margin, and Lefty is required to restrict the range of Nodal signaling by blocking both the generation of Nodal locally and the response to Nodal at a distance (Meno et al. 1999; Chen and Schier 2002). The Nodal/Lefty interaction occurs in three steps: (1) Nodal expression is activated, resulting in pathway activation. (2) Pathway activation results in Lefty expression. (3) Lefty inhibits the pathway.

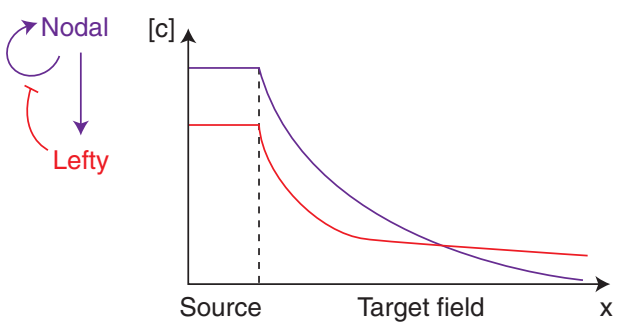

Figure 4. Reaction/Diffusion Model for Patterning by Nodal and Lefty. Nodal induces its own expression and forms a concentration gradient ( $c$, concentrations of Nodal and Lefty; $x$, distance). Lefty is induced by Nodal and blocks Nodal signaling. The model postulates that Lefty has a longer range and more shallow distribution than Nodal. Thus, Nodal signaling is active close to the source but inhibited at a distance. See text for details. 


\section{A.F. Schier}

The exact pattern of pathway activation depends on the local concentrations of Nodal and Lefty. In the blastula, genetic experiments indicate that Squint and Cyclops are in excess close to the source, whereas Lefty is present at higher levels at a distance from the source (Chen and Schier 2002). In the absence of Lefty, more Nodal is generated, and cells at a distance are no longer inhibited by Lefty. On excess of Lefty, Nodal production and signaling are inhibited. Thus, Nodal/Lefty constitute a reaction-diffusion activator/inhibitor pair but they do not generate pattern de novo in an initially homogenous field of cells (Fig. 2). Rather, localized maternal determinants activate Nodal expression, which then induces Lefty. The Nodal/Lefty interaction is also an example of how a morphogen, Nodal, can modulate its effects by inducing a secondary signal, Lefty. Thus, target cells are not merely passive responders but change the activity gradient by their response.

The Nodal/Lefty activator/inhibitor pair also plays a role during left-right specification (Hamada et al. 2002; Nakamura et al. 2006). In this system, Nodal/Lefty interactions appear to amplify small differences between left and right lateral plate mesoderm (Fig. 3). Both left and right can initially express low levels of Nodal but by an unknown mechanism, ciliainduced flow in the node is thought to generate a slightly higher accumulation of Nodal in left lateral plate mesoderm. This initial asymmetry is amplified by Nodal autoregulation and the induction of Lefty on the left and in the midline. The long-range activity of leftsided and midline Lefty then suppresses Nodal amplification on the right. Mathematical modeling supports this self-enhancement lateral inhibition model (Nakamura et al. 2006). As in the blastula, this system is not entirely selforganizing but biased by a prepattern. In contrast to the blastula, however, the output is not graded but discrete: On (left) versus off (right).

Taken together, these studies have provided strong genetic evidence that Nodal/Lefty are part of a two-component reaction-diffusion system. However, the presumptive long-range distributions of Nodal and Lefty proteins have not been visualized in vivo, and it remains unclear how exactly their interaction provides positional information.

\section{Modulation of Nodal Morphogen Activity}

The distribution and activity of morphogens are controlled by multiple factors. Prominent roles are played by the rate and level of morphogen production at the source, the rate of morphogen movement from the source into surrounding tissues, and the availability and stability of the morphogen. For example, the higher the production, diffusion, and stability of a morphogen, the longer is its range. Conversely, the effects of morphogens are determined by the responsiveness of target cells. For example, receptor levels and inhibitors can influence cellular responses. In the following section, some of the molecular mechanisms that modulate the range and activity of Nodal morphogens is discussed. It is worth emphasizing, however, that this analysis is still in its infancy. For example, when experimental manipulations change the Nodal signaling range or response, it is often unclear whether this change is caused by alterations in morphogen production, mobility, trafficking or stability, changes in regulatory feedback interactions, or differences in target cell responsiveness.

\section{Expression}

The concentrations and ratio of Nodal and Lefty signals determine the range of Nodal signaling-the more Nodal and the less Lefty, the higher the activation of the pathway. The expression levels of these genes must therefore be exquisitely regulated. For instance, in frog and zebrafish, Nodal genes are first activated on the future dorsal side and then are expressed in the vegetal and marginal region of the blastula (Schier 2003). This expression pattern is reflected in the activation of the pathway. In frogs, P-Smad2 is first detected on the dorsal side, and in zebrafish, nuclear Smad2 levels are highest in dorsal blastomeres (Faure et al. 2000; Lee et al. 2001; Harvey and Smith 2009). Correspondingly, genetic studies have shown 
that the induction of dorsal mesodermal cell fates requires higher levels of Nodal signaling than ventral and lateral mesoderm, and misexpression studies have revealed that the induction of dorsal mesoderm markers such as gsc requires higher levels of Nodal signaling than the induction of pan-mesodermal genes such as ntl (Schier et al. 1997; Gritsman et al. 2000; Dougan et al. 2003). Moreover, fate mapping studies have shown that partial reduction of Nodal signaling leads to the loss of dorsal mesodermal cell fates (Gritsman et al. 2000; Dougan et al. 2003). Instead, these cells acquire more animal cell fates and form neural structures. Importantly, no transformation into more ventral mesodermal cell fates is observed on inhibition of Nodal signaling. Thus, despite higher nuclear accumulation of Smad2 on the dorsal side and the suggestion that Nodal signaling patterns mesoderm along the dorsalventral axis (Harvey and Smith 2009), there is no evidence for a requirement of graded Nodal signaling in specifying dorsal versus ventral mesodermal fates. Rather, graded Nodal signaling patterns the vegetal-animal axis and blocks the formation of neural structures at the dorsal margin (Feldman et al. 2000; Carmany-Rampey and Schier 2001; Dougan et al. 2003).

Following the induction of Nodal gene expression, regulatory interactions between Nodal and Lefty generate an intricate system to modulate Nodal signaling. Nodal activates its own transcription, which if unchecked results in a positive feedback that dramatically increases Nodal gene expression. However, because Nodal also activates Lefty expression and Lefty inhibits pathway activity, a negative feedback dampens, spatially restricts, and temporally attenuates Nodal signaling (Meno et al. 1999; Chen and Schier 2002; Feldman et al. 2002; Dougan et al. 2003). It is still unclear how exactly these auto- and crossregulatory interactions contribute to the robustness and precision of patterning, but recent evidence suggests that the balance of Nodal/Lefty is carefully regulated not only at the level of transcription but also posttranscriptionally by microRNAs. In particular, zebrafish miR-430 dampens the mRNA levels and translation of Squint, lefty1, and lefty2 (Choi et al. 2007), one of the many roles of this microRNA (Giraldez et al. 2005; Giraldez et al. 2006; Mishima et al. 2006). In the absence of miR-430, both agonist and antagonist are up-regulated. Intriguingly, this up-regulation leads to an imbalance of Nodal versus Lefty inputs, so that Lefty activity prevails and Nodal signaling is reduced. It is unclear why Lefty derepression dominates Squint derepression. It is conceivable that Lefty is misexpressed at higher levels than Squint on loss of miR-430 repression. Alternatively, it is possible that nonlinear steps in Nodal/Lefty regulation favor inhibition of the pathway in the absence of miR-430. A similar inhibition of Nodal antagonism is observed in human ES cells, where the miR-430 orthologue miR-302 is required to repress Lefty and promote mesendoderm development (Rosa et al. 2009).

MicroRNAs have also been implicated in the regulation of type II activin receptor expression. Xenopus miR-15/16 is expressed in ventrallateral regions and inhibits type II Activin receptor expression (Martello et al. 2007). This results in higher activin receptor levels in dorsal compared with ventral blastomeres, resulting in higher responsiveness to Nodal signals on the dorsal side. This effect is further augmented by Rap2, which is involved in recycling of Activin receptors (Choi et al. 2008). Rap2 is initially enriched dorsally and thus also contributes to higher receptor levels and thus the earlier and higher induction of Nodal signaling in dorsal blastomeres. These studies demonstrate that microRNAs are important modulators of Nodal morphogen signaling.

\section{Stability and Movement}

Nodal pathway activation in a field of cells is not only dependent on the levels of Nodal and Lefty at the source, but also on the levels that reach target cells. These levels are determined by the movement and stability of Nodal and Leftythe more stable and mobile, the longer the range of the signal. 


\section{A.F. Schier}

The movement of Nodal proteins is poorly understood. It has been shown in Xenopus explants that the Nodal protein Xnr2 is distributed through extracellular routes and not through uptake and release from cells, a process called transcytosis (Williams et al. 2004). It is unclear, however, if this extracellular movement is purely diffusive or if active transport is involved. Studies of the TGF- $\beta$ signals Activin and Dpp favor this possibility, but detailed biophysical studies are required to directly test Nodal diffusion (McDowell et al. 1997; Kinoshita et al. 2006; Kicheva et al. 2007; Kicheva and Gonzalez-Gaitan 2008). Such studies are also crucial to determine whether the different activity ranges of Squint, Cyclops, and Lefty are because of different diffusibilities. For example, studies of Dpp have measured a diffusion coefficient of $0.1 \mu \mathrm{m}^{2} / \mathrm{s}$ in imaginal discs (Kicheva et al. 2007; Kicheva and Gonzalez-Gaitan 2008). Modeling studies indicate that this value would only allow shortrange signaling within the $2-3$ hour time frame during which the zebrafish blastula is patterned by Nodal signals (Lee, Robson, and Schier, unpublished results). Hence, it is unclear how diffusibility contributes to the range of Nodal signaling. This is a particularly important issue because one of the tenets of reactiondiffusion models is that the inhibitor (Lefty) has a longer range than the activator (Nodal).

It is also unclear how processing, stability, post-translational modifications, and trafficking contribute to the range of Nodal signals. Different Nodal signals can have different signaling ranges. For instance, Cyclops has a shorter signaling range than Squint (Chen and Schier 2001). The differences in range are thought to be caused by differences in both the prodomains and mature domains (Chen and Schier 2001; Jing et al. 2006; Tian et al. 2008). For example, a chimeric protein consisting of the Cyclops prodomain and Squint mature domain has a longer range than Cyclops protein but a shorter range than Squint. An acidic region in the amino terminus of the Squint mature ligand is required for the longer range of the Cyclops-Squint chimera (Jing et al. 2006). Conversely, a presumptive lysosomal targeting region in the Cyclops prodomain restricts its range (Tian et al. 2008). Expression of the mature domain of Squint or mouse Nodal results in an unstable signal that only acts at a short range, whereas the mature domain of Cyclops does not have any activity by itself and requires the prodomain (Le Good et al. 2005; Tian et al. 2008). In contrast, insertion of an $\mathrm{N}$-glycosylation site increases the stability of mouse Nodal in cell culture and extends its range in zebrafish embryos (Le Good et al. 2005). These results have suggested that increased proteolytic maturation of Nodal potentiates local signaling, whereas increased Nodal stability extends long-range signaling. In tissue culture, Nodal precursor is more stable than processed Nodal, indicating that the site and timing of processing might influence the range of signaling (Blanchet et al. 2008a; Constam 2009). Interaction with EGF-CFC proteins can target mouse Nodal into specific endocytic compartments and might thus also contribute to the stability and intracellular movement of Nodal ligands (Le Good et al. 2005; Blanchet et al. 2008a; Blanchet et al. 2008b). These studies suggest that the location and regulation of Nodal processing plays a major role in determining stability and range.

The range of Nodal signaling is modulated by additional extracellular proteins. For example, Nodal secreted in the node can activate signaling in the distant LPM only in the presence of the glycosaminoglycan chondroitin sulfate (Oki et al. 2007). Because ectopic Nodal can still activate the pathway on chondroitin sulfate perturbation, it is likely that the interaction of Nodal with sulfated glycosaminoglycans increases ligand movement or stability and not receptor binding or activation.

Further complexity arises from the potential for TGF- $\beta$ heterodimer formation. For example, the related TGB- $\beta$ signal GDF1 is also involved in left-right specification (Rankin et al. 2000). Similar to Nodal, it is expressed in the node and LPM. Node expression is required for left-sided activation of Nodal target genes, and expression in the LPM is required for the expansion of Nodal signaling in the LPM. Native GDF1 homodimers appear 
largely inactive but GDF1/Nodal heterodimers are active and even more potent than Nodal homodimers in activating Nodal reporter genes (Tanaka et al. 2007). These heterodimers also have a longer activity range but it is unclear if this is only because of increased specific activity in pathway activation or also caused by increased diffusion or stability.

\section{Interpretation}

The mechanisms underlying the interpretation of Nodal signals in target cells are poorly understood. Studies of Activin in Xenopus have revealed a linear relationship of TGF- $\beta$ concentration, receptor activation, Smad complex formation, and downstream gene activation (Gurdon and Bourillot 2001). Moreover, Activin can act in a ratchet mechanism, i.e., cells have a memory of the highest levels of Activin they have been exposed to and respond accordingly. This memory resides at the level of receptor-ligand complexes and is maintained by the intracellular localization of signaling complexes in endosomes (Jullien and Gurdon 2005). It is unclear whether Nodal signals behave similarly to Activin. For example, Activin is not dependent on EGF-CFC proteins for pathway activation and cannot be inhibited by Leftys (Gritsman et al. 1999; Cheng et al. 2004). Thus, it is possible that Nodal-receptor complexes are disrupted by Lefty, undermining potential ratchet mechanisms and pathway linearity.

Finally, it is not clear how Nodal target genes respond to different levels of Nodal signaling. Based on studies of other morphogens, it is assumed that the differential affinity for cisregulatory elements determines the threshold at which a downstream gene is activated. The responses of known downstream genes to different concentrations of Nodal are consistent with this model, but direct evidence is lacking. The situation is further complicated by the existence of maternally generated prepatterns in early fish and frog embryos. The localization of pathway antagonists in the presumptive ectoderm changes the response properties of target tissues and complicates simple models wherein a naïve group of cells homogeneously responds to different morphogen concentrations. For example, ectodermin is maternally expressed and localized to the animal pole in Xenopus, thus creating a zone that is less responsive to Nodal and BMP signals (Dupont et al. 2005; Dupont et al. 2009). Additional transcription factors such as Sox3, Xema/FoxIle, Serum response factor, and XFDL156, and the Cerberus-like protein Coco are also expressed in presumptive ectoderm and protect ectoderm from Nodal inducers (Bell et al. 2003; Suri et al. 2005; Mir et al. 2007; Yun et al. 2007; Zhang and Klymkowsky 2007; Sasai et al. 2008). Thus, prepatterning will modulate the generation of and response to Nodal signaling gradients.

\section{CONCLUDING REMARKS}

Studies of Nodal signaling led to the discovery of the bona fide mesendoderm inducers and left-right determinants, identified the first endogenous vertebrate morphogen, established the existence of an activator/inhibitor pair as postulated in reaction-diffusion models, revealed roles for microRNAs in morphogen signaling and highlighted the complex roles of processing, trafficking, and post-translational modifications during morphogen signaling. Despite this progress, a quantitative or biophysical understanding of Nodal morphogens is largely elusive. We do not know the shape of the putative Nodal morphogen gradient, the in vivo diffusion, processing, trafficking, and degradation properties of Nodal and Lefty, the binding and reaction kinetics of the pathway components, the mechanisms by which signal concentration and duration are translated into positional information, or the robustness and precision encoded by the Nodal morphogen gradient. Filling these gaps will be necessary to truly understand how the Nodal morphogen patterns developing tissues.

\section{ACKOWLEDGMENTS}

I thank Daniel Constam, Susan Mango, Michael Shen, Will Talbot, and members of my lab for comments on the manuscript, and the NIH, 


\section{A.F. Schier}

McKnight Endowment Fund for Neuroscience, American Heart Association, Irma T. Hirschl Fund, HFSP, Skirball Institute of New York University Medical Center, and Harvard University for past and current support.

\section{REFERENCES}

Adachi H, Saijoh Y, Mochida K, Ohishi S, Hashiguchi H, Hirao A, Hamada H. 1999. Determination of left/right asymmetric expression of nodal by a left side-specific enhancer with sequence similarity to a lefty- 2 enhancer. Genes Dev 13: 1589-1600.

Agathon A, Thisse B, Thisse C. 2001. Morpholino knockdown of antivin 1 and antivin2 upregulates nodal signaling. Genesis 30: 178-182.

Agius E, Oelgeschlager M, Wessely O, Kemp C, De Robertis EM. 2000. Endodermal Nodal-related signals and mesoderm induction in Xenopus. Development 127: 1173-1183.

Andersson O, Bertolino P, Ibanez CF. 2007. Distinct and cooperative roles of mammalian Vg1 homologs GDF1 and GDF3 during early embryonic development. Dev Biol 311: 500-511.

Andersson O, Reissmann E, Jornvall H, Ibanez CF. 2006. Synergistic interaction between Gdf1 and Nodal during anterior axis development. Dev Biol 293: 370-381.

Aoki TO, David NB, Minchiotti G, Saint-Etienne L, Dickmeis T, Persico GM, Strahle U, Mourrain P, Rosa FM. 2002. Molecular integration of casanova in the Nodal signalling pathway controlling endoderm formation. Development 129: 275-286.

Arnold SJ, Robertson EJ. 2009. Making a commitment: Cell lineage allocation and axis patterning in the early mouse embryo. Nat Rev Mol Cell Biol 10: 91-103.

Ashe HL, Briscoe J. 2006. The interpretation of morphogen gradients. Development 133: 385-394

Baker K, Holtzman NG, Burdine RD. 2008. Direct and indirect roles for Nodal signaling in two axis conversions during asymmetric morphogenesis of the zebrafish heart. Proc Natl Acad Sci 105: 13924-13929.

Bakkers J, Verhoeven MC, Abdelilah-Seyfried S. 2009 Shaping the zebrafish heart: From left-right axis specification to epithelial tissue morphogenesis. Dev Biol 330: 213-220.

Bamford RN, Roessler E, Burdine RD, Saplakoglu U, dela Cruz J, Splitt M, Goodship JA, Towbin J, Bowers P, Ferrero GB, et al. 2000. Loss-of-function mutations in the EGF-CFC gene CFC1 are associated with human left-right laterality defects. Nat Genet 26: 365-369.

Batut J, Schmierer B, Cao J, Raftery LA, Hill CS, Howell M. 2008. Two highly related regulatory subunits of PP2A exert opposite effects on TGF- $\beta$ /Activin/Nodal signalling. Development 135: 2927-2937.

Beck S, Le Good JA, Guzman M, Ben Haim N, Roy K, Beermann F, Constam DB. 2002. Extraembryonic proteases regulate Nodal signalling during gastrulation. Nat Cell Biol 4: 981-985.

Bell E, Munoz-Sanjuan I, Altmann CR, Vonica A, Brivanlou AH. 2003. Cell fate specification and competence by
Coco, a maternal BMP, TGF $\beta$ and Wnt inhibitor. Development 130: 1381-1389.

Belo JA, Silva AC, Borges AC, Filipe M, Bento M, Gonalves L, Vitorino M, Salgueiro AM, Texeira V, Tavares AT, et al. 2008. Generating asymmetries in the early vertebrate embryo: The role of the Cerberus-like family. Int $J$ Dev Biol doi: 10.1387/ijdb.072297jb.

Ben-Haim N, Lu C, Guzman-Ayala M, Pescatore L, Mesnard D, Bischofberger M, Naef F, Robertson EJ, Constam DB. 2006. The nodal precursor acting via activin receptors induces mesoderm by maintaining a source of its convertases and BMP4. Dev Cell 11: 313-323.

Bennett JT, Joubin K, Cheng S, Aanstad P, Herwig R, Clark M, Lehrach H, Schier AF. 2007a. Nodal signaling activates differentiation genes during zebrafish gastrulation. Dev Biol 304: 525-540.

Bennett JT, Stickney HL, Choi WY, Ciruna B, Talbot WS, Schier AF. 2007b. Maternal nodal and zebrafish embryogenesis. Nature 450: E1-2; discussion E2-4.

Bertocchini F, Stern CD. 2002. The hypoblast of the chick embryo positions the primitive streak by antagonizing nodal signaling. Dev Cell 3: 735-744.

Bisgrove BW, Essner JJ, Yost HJ. 1999. Regulation of midline development by antagonism of lefty and nodal signaling. Development 126: 3253-3262.

Blanchet MH, Le Good JA, Mesnard D, Oorschot V, Baflast S, Minchiotti G, Klumperman J, Constam DB. 2008a. Cripto recruits Furin and PACE4 and controls Nodal trafficking during proteolytic maturation. Embo $J$ 27: 2580-2591.

Blanchet MH, Le Good JA, Oorschot V, Baflast S, Minchiotti G, Klumperman J, Constam DB. 2008b. Cripto localizes Nodal at the limiting membrane of early endosomes. Sci Signal 1: ra13.

Bourillot PY, Garrett N, Gurdon JB. 2002. A changing morphogen gradient is interpreted by continuous transduction flow. Development 129: 2167-2180.

Bouwmeester T, Kim S, Sasai Y, Lu B, De Robertis EM. 1996. Cerberus is a head-inducing secreted factor expressed in the anterior endoderm of Spemann's organizer. Nature 382: 595-601.

Brandenberger R, Wei H, Zhang S, Lei S, Murage J, Fisk GJ, Li Y, Xu C, Fang R, Guegler K, et al. 2004. Transcriptome characterization elucidates signaling networks that control human ES cell growth and differentiation. Nat Biotechnol 22: 707-716.

Brennan J, Norris DP, Robertson EJ. 2002. Nodal activity in the node governs left-right asymmetry. Genes Dev 16: 2339-2344.

Brennan J, Lu CC, Norris DP, Rodriguez TA, Beddington RS, Robertson EJ. 2001. Nodal signalling in the epiblast patterns the early mouse embryo. Nature 411: 965-969.

Camus A, Perea-Gomez A, Moreau A, Collignon J. 2006. Absence of Nodal signaling promotes precocious neural differentiation in the mouse embryo. Dev Biol 295: $743-755$.

Carmany-Rampey A, Schier AF. 2001. Single-cell internalization during zebrafish gastrulation. Curr Biol 11: $1261-1265$. 
Chea HK, Wright CV, Swalla BJ. 2005. Nodal signaling and the evolution of deuterostome gastrulation. Dev Dyn 234: 269-278.

Chen Y, Schier AF. 2001. The zebrafish Nodal signal Squint functions as a morphogen. Nature 411: 607-610.

Chen Y, Schier AF. 2002. Lefty proteins are long-range inhibitors of squint-mediated nodal signaling. Curr Biol 12: 2124-2128.

Chen C, Shen MM. 2004. Two modes by which Lefty proteins inhibit nodal signaling. Curr Biol 14: 618-624.

Chen X, Rubock MJ, Whitman M. 1996. A transcriptional partner for MAD proteins in TGF- $\beta$ signalling. Nature 383: 691-696.

Chen C, Ware SM, Sato A, Houston-Hawkins DE, Habas R, Matzuk MM, Shen MM, Brown CW. 2006. The Vg1-related protein Gdf3 acts in a Nodal signaling pathway in the pre-gastrulation mouse embryo. Development 133: 319-329.

Cheng SK, Olale F, Bennett JT, Brivanlou AH, Schier AF. 2003. EGF-CFC proteins are essential coreceptors for the TGF- $\beta$ signals Vg1 and GDF1. Genes Dev 17: 31-36.

Cheng SK, Olale F, Brivanlou AH, Schier AF. 2004. Lefty blocks a subset of TGF $\beta$ signals by antagonizing EGF-CFC coreceptors. PLoS Biol 2: E30.

Choi WY, Giraldez AJ, Schier AF. 2007. Target protectors reveal dampening and balancing of Nodal agonist and antagonist by miR-430. Science 318: 271-274.

Choi SC, Kim GH, Lee SJ, Park E, Yeo CY, Han JK. 2008. Regulation of activin/nodal signaling by Rap2-directed receptor trafficking. Dev Cell 15: 49-61.

Chu J, Ding J, Jeays-Ward K, Price SM, Placzek M, Shen MM. 2005. Non-cell-autonomous role for Cripto in axial midline formation during vertebrate embryogenesis. Development 132: 5539-5551.

Collignon J, Varlet I, Robertson EJ. 1996. Relationship between asymmetric nodal expression and the direction of embryonic turning. Nature 381: 155-158.

Concha ML, Burdine RD, Russell C, Schier AF, Wilson SW. 2000. A nodal signaling pathway regulates the laterality of neuroanatomical asymmetries in the zebrafish forebrain. Neuron 28: 399-409.

Concha ML, Russell C, Regan JC, Tawk M, Sidi S, Gilmour DT, Kapsimali M, Sumoy L, Goldstone K, Amaya E, et al. 2003. Local tissue interactions across the dorsal midline of the forebrain establish CNS laterality. Neuron 39: 423-438.

Conlon FL, Barth KS, Robertson EJ. 1991. A novel retrovirally induced embryonic lethal mutation in the mouse: Assessment of the developmental fate of embryonic stem cells homozygous for the 413.d proviral integration. Development 111: 969-981.

Conlon FL, Lyons KM, Takaesu N, Barth KS, Kispert A, Herrmann B, Robertson EJ. 1994. A primary requirement for nodal in the formation and maintenance of the primitive streak in the mouse. Development 120: 1919-1928.

Constam DB. 2009. Riding shotgun: A dual role for the EGF-CFC protein Cripto in Nodal trafficking. Traffic 10: $783-791$.

Cordenonsi M, Dupont S, Maretto S, Insinga A, Imbriano C, Piccolo S. 2003. Links between tumor suppressors: p53 is required for TGF- $\beta$ gene responses by cooperating with Smads. Cell 113: 301-314.

Cordenonsi M, Montagner M, Adorno M, Zacchigna L, Martello G, Mamidi A, Soligo S, Dupont S, Piccolo S. 2007. Integration of TGF- $\beta$ and Ras/MAPK signaling through p53 phosphorylation. Science 315: 840-843.

D’Amour KA, Agulnick AD, Eliazer S, Kelly OG, Kroon E, Baetge EE. 2005. Efficient differentiation of human embryonic stem cells to definitive endoderm. Nat Biotechnol 23: 1534-1541.

Dai F, Lin X, Chang C, Feng XH. 2009. Nuclear export of Smad 2 and Smad3 by RanBP3 facilitates termination of TGF- $\beta$ signaling. Dev Cell 16: 345-357.

Davis NM, Kurpios NA, Sun X, Gros J, Martin JF, Tabin CJ. 2008. The chirality of gut rotation derives from left-right asymmetric changes in the architecture of the dorsal mesentery. Dev Cell 15: 134-145.

de Campos-Baptista MI, Holtzman NG, Yelon D, Schier AF. 2008. Nodal signaling promotes the speed and directional movement of cardiomyocytes in zebrafish. Dev Dyn 237: 3624-3633.

de la Cruz JM, Bamford RN, Burdine RD, Roessler E, Barkovich AJ, Donnai D, Schier AF, Muenke M. 2002. A loss-of-function mutation in the CFC domain of TDGF1 is associated with human forebrain defects. Hum Genet 110: 422-428.

Di Guglielmo GM, Le Roy C, Goodfellow AF, Wrana JL. 2003. Distinct endocytic pathways regulate TGF- $\beta$ receptor signalling and turnover. Nat Cell Biol 5: 410-421.

Dickmeis T, Aanstad P, Clark M, Fischer N, Herwig R, Mourrain P, Blader P, Rosa F, Lehrach H, Strahle U. 2001. Identification of nodal signaling targets by array analysis of induced complex probes. Dev Dyn 222: 571-580.

Ding J, Yang L, Yan YT, Chen A, Desai N, Wynshaw-Boris A, Shen MM. 1998. Cripto is required for correct orientation of the anterior-posterior axis in the mouse embryo. Nature 395: 702-707.

Dorey K, Hill CS. 2006. A novel Cripto-related protein reveals an essential role for EGF-CFCs in Nodal signalling in Xenopus embryos. Dev Biol 292: 303-316.

Dougan ST, Warga RM, Kane DA, Schier AF, Talbot WS. 2003. The role of the zebrafish nodal-related genes squint and cyclops in patterning of mesendoderm. Development 130: 1837-1851.

Duboc V, Rottinger E, Besnardeau L, Lepage T. 2004. Nodal and BMP2/4 signaling organizes the oral-aboral axis of the sea urchin embryo. Dev Cell 6: 397-410.

Dupont S, Mamidi A, Cordenonsi M, Montagner M, Zacchigna L, Adorno M, Martello G, Stinchfield MJ, Soligo S, Morsut L, et al. 2009. FAM/USP9x, a deubiquitinating enzyme essential for TGF $\beta$ signaling, controls Smad4 monoubiquitination. Cell 136: 123-135.

Dupont S, Zacchigna L, Cordenonsi M, Soligo S, Adorno M, Rugge M, Piccolo S. 2005. Germ-layer specification and control of cell growth by Ectodermin, a Smad4 ubiquitin ligase. Cell 121: 87-99.

Dyson S, Gurdon JB. 1998. The interpretation of position in a morphogen gradient as revealed by occupancy of activin receptors. Cell 93: 557-568. 


\section{A.F. Schier}

Episkopou V, Arkell R, Timmons PM, Walsh JJ, Andrew RL, Swan D. 2001. Induction of the mammalian node requires Arkadia function in the extraembryonic lineages. Nature 410: 825-830.

Erter CE, Solnica-Krezel L, Wright CV. 1998. Zebrafish nodal-related 2 encodes an early mesendodermal inducer signaling from the extraembryonic yolk syncytial layer. Dev Biol 204: 361-372.

Faucourt M, Houliston E, Besnardeau L, Kimelman D, Lepage T. 2001. The pitx2 homeobox protein is required early for endoderm formation and nodal signaling. Dev Biol 229: 287-306.

Faure S, Lee MA, Keller T, ten Dijke P, Whitman M. 2000. Endogenous patterns of TGF $\beta$ superfamily signaling during early Xenopus development. Development 127: 2917-2931.

Feldman B, Concha ML, Saude L, Parsons MJ, Adams RJ, Wilson SW, Stemple DL. 2002. Lefty antagonism of Squint is essential for normal gastrulation. Curr Biol 12: 2129-2135.

Feldman B, Dougan ST, Schier AF, Talbot WS. 2000. Nodal-related signals establish mesendodermal fate and trunk neural identity in zebrafish. Curr Biol 10: 531-534.

Feldman B, Gates MA, Egan ES, Dougan ST, Rennebeck G, Sirotkin HI, Schier AF, Talbot WS. 1998. Zebrafish organizer development and germ-layer formation require nodal-related signals. Nature 395: 181-185.

Germain S, Howell M, Esslemont GM, Hill CS. 2000. Homeodomain and winged-helix transcription factors recruit activated Smads to distinct promoter elements via a common Smad interaction motif. Genes Dev 14: $435-451$.

Giraldez AJ, Cinalli RM, Glasner ME, Enright AJ, Thomson JM, Baskerville S, Hammond SM, Bartel DP, Schier AF 2005. MicroRNAs regulate brain morphogenesis in zebrafish. Science 308: 833-838.

Giraldez AJ, Mishima Y, Rihel J, Grocock RJ, Van Dongen S, Inoue K, Enright AJ, Schier AF. 2006. Zebrafish MiR-430 promotes deadenylation and clearance of maternal mRNAs. Science 312: 75-79.

Grande C, Patel NH. 2009. Nodal signalling is involved in left-right asymmetry in snails. Nature 457: 1007-1011.

Gritsman K, Talbot WS, Schier AF. 2000. Nodal signaling patterns the organizer. Development 127: 921-932.

Gritsman K, Zhang J, Cheng S, Heckscher E, Talbot WS, Schier AF. 1999. The EGF-CFC protein one-eyed pinhead is essential for nodal signaling. Cell 97: 121-132.

Gurdon JB, Bourillot PY. 2001. Morphogen gradient interpretation. Nature 413: 797-803.

Gurdon JB, Harger P, Mitchell A, Lemaire P. 1994. Activin signalling and response to a morphogen gradient. Nature 371: 487-492.

Guzman-Ayala M, Lee KL, Mavrakis KJ, Goggolidou P, Norris DP, Episkopou V. 2009. Graded Smad2/3 activation is converted directly into levels of target gene expression in embryonic stem cells. PLoS ONE 4: e4268.

Hagos EG, Dougan ST. 2007. Time-dependent patterning of the mesoderm and endoderm by Nodal signals in zebrafish. BMC Dev Biol 7: 22.
Halpern ME, Liang JO, Gamse JT. 2003. Leaning to the left: Laterality in the zebrafish forebrain. Trends Neurosci 26: 308-313.

Hamada H, Meno C, Watanabe D, Saijoh Y. 2002. Establishment of vertebrate left-right asymmetry. Nat Rev Genet 3: 103-113.

Hart AH, Hartley L, Sourris K, Stadler ES, Li R, Stanley EG, Tam PP, Elefanty AG, Robb L. 2002. Mixll is required for axial mesendoderm morphogenesis and patterning in the murine embryo. Development 129: 3597-3608.

Harvey SA, Smith JC. 2009. Visualisation and Quantification of Morphogen Gradient Formation in the Zebrafish. PLoS Biol 7: e101.

Hashimoto H, Rebagliati M, Ahmad N, Muraoka O, Kurokawa T, Hibi M, Suzuki T. 2004. The Cerberus Dan-family protein Charon is a negative regulator of Nodal signaling during left-right patterning in zebrafish. Development 131: 1741-1753.

Heasman J. 2006. Patterning the early Xenopus embryo. Development 133: 1205-1217.

Hoodless PA, Pye M, Chazaud C, Labbe E, Attisano L, Rossant J, Wrana JL. 2001. FoxH1 (Fast) functions to specify the anterior primitive streak in the mouse. Genes Dev 15: 1257-1271.

Inman GJ, Nicolas FJ, Hill CS. 2002. Nucleocytoplasmic shuttling of Smads 2, 3, and 4 permits sensing of TGF- $\beta$ receptor activity. Mol Cell 10: 283-294.

Iratni R, Yan YT, Chen C, Ding J, Zhang Y, Price SM, Reinberg D, Shen MM. 2002. Inhibition of excess nodal signaling during mouse gastrulation by the transcriptional corepressor DRAP1. Science 298: 1996-1999.

James D, Levine AJ, Besser D, Hemmati-Brivanlou A. 2005. TGF $\beta$ /activin/nodal signaling is necessary for the maintenance of pluripotency in human embryonic stem cells. Development 132: 1273-1282.

Jing XH, Zhou SM, Wang WQ, Chen Y. 2006. Mechanisms underlying long- and short-range nodal signaling in Zebrafish. Mech Dev 123: 388-394.

Jones CM, Armes N, Smith JC. 1996. Signalling by TGF- $\beta$ family members: Short-range effects of Xnr-2 and BMP-4 contrast with the long-range effects of activin. Curr Biol 6: 1468-1475.

Jones CM, Kuehn MR, Hogan BL, Smith JC, Wright CV. 1995. Nodal-related signals induce axial mesoderm and dorsalize mesoderm during gastrulation. Development 121: $3651-3662$.

Joseph EM, Melton DA. 1997. Xnr4: A Xenopus nodalrelated gene expressed in the Spemann organizer. Dev Biol 184: 367-372.

Jullien J, Gurdon J. 2005. Morphogen gradient interpretation by a regulated trafficking step during ligand-receptor transduction. Genes Dev 19: 2682-2694.

Karkera JD, Lee JS, Roessler E, Banerjee-Basu S, Ouspenskaia MV, Mez J, Goldmuntz E, Bowers P, Towbin J, Belmont JW, et al. 2007. Loss-of-function mutations in growth differentiation factor-1 (GDF1) are associated with congenital heart defects in humans. Am J Hum Genet 81: 987-994.

Kicheva A, Gonzalez-Gaitan M. 2008. The Decapentaplegic morphogen gradient: A precise definition. Curr Opin Cell Biol 20: $137-143$. 
Kicheva A, Pantazis P, Bollenbach T, Kalaidzidis Y, Bittig T, Julicher F, Gonzalez-Gaitan M. 2007. Kinetics of morphogen gradient formation. Science 315: 521-525.

Kikuchi Y, Trinh LA, Reiter JF, Alexander J, Yelon D, Stainier DY. 2000. The zebrafish bonnie and clyde gene encodes a Mix family homeodomain protein that regulates the generation of endodermal precursors. Genes Dev 14: 1279-1289.

Kimelman D, Schier AF. 2002. Mesoderm induction and patterning. Results Probl Cell Differ 40: 15-27.

Kinoshita T, Jullien J, Gurdon JB. 2006. Two-dimensional morphogen gradient in Xenopus: Boundary formation and real-time transduction response. Dev Dyn 235: 3189-3198.

Koinuma D, Shinozaki M, Komuro A, Goto K, Saitoh M, Hanyu A, Ebina M, Nukiwa T, Miyazawa K, Imamura T, et al. 2003. Arkadia amplifies TGF- $\beta$ superfamily signalling through degradation of Smad7. Embo $J$ 22: 6458-6470.

Kubo A, Shinozaki K, Shannon JM, Kouskoff V, Kennedy M, Woo S, Fehling HJ, Keller G. 2004. Development of definitive endoderm from embryonic stem cells in culture. Development 131: 1651-1662.

Kumar A, Lualdi M, Lewandoski M, Kuehn MR. 2008. Broad mesodermal and endodermal deletion of Nodal at postgastrulation stages results solely in left/right axial defects. Dev Dyn 237: 3591-3601.

Kunwar PS, Zimmerman S, Bennett JT, Chen Y, Whitman M, Schier AF. 2003. Mixer/Bon and FoxH1/Sur have overlapping and divergent roles in Nodal signaling and mesendoderm induction. Development 130: 5589-5599.

Kurpios NA, Ibanes M, Davis NM, Lui W, Katz T, Martin JF, Belmonte JC, Tabin CJ. 2008. The direction of gut looping is established by changes in the extracellular matrix and in cell:cell adhesion. Proc Natl Acad Sci 105: 8499-8506.

Le Good JA, Joubin K, Giraldez AJ, Ben-Haim N, Beck S, Chen Y, Schier AF, Constam DB. 2005. Nodal stability determines signaling range. Curr Biol 15: 31-36.

Lee MA, Heasman J, Whitman M. 2001. Timing of endogenous activin-like signals and regional specification of the Xenopus embryo. Development 128: 2939-2952.

Levin M, Johnson RL, Stern CD, Kuehn M, Tabin C. 1995. A molecular pathway determining left-right asymmetry in chick embryogenesis. Cell 82: 803-814.

Levy L, Howell M, Das D, Harkin S, Episkopou V, Hill CS. 2007. Arkadia activates Smad3/Smad4-dependent transcription by triggering signal-induced SnoN degradation. Mol Cell Biol 27: 6068-6083.

Lin X, Duan X, Liang YY, Su Y, Wrighton KH, Long J, Hu M, Davis CM, Wang J, Brunicardi FC, et al. 2006. PPM1A functions as a Smad phosphatase to terminate TGF $\beta$ signaling. Cell 125: 915-928.

Long S, Ahmad N, Rebagliati M. 2003. The zebrafish nodalrelated gene southpaw is required for visceral and diencephalic left-right asymmetry. Development 130: 2303-2316.

Lowe LA, Yamada S, Kuehn MR. 2001. Genetic dissection of nodal function in patterning the mouse embryo. Development 128: 1831-1843.
Lowe LA, Supp DM, Sampath K, Yokoyama T, Wright CV, Potter SS, Overbeek P, Kuehn MR. 1996. Conserved left-right asymmetry of nodal expression and alterations in murine situs inversus. Nature 381: 158-161.

Marques S, Borges AC, Silva AC, Freitas S, Cordenonsi M, Belo JA. 2004. The activity of the Nodal antagonist Cerl-2 in the mouse node is required for correct L/R body axis. Genes Dev 18: 2342-2347.

Martello G, Zacchigna L, Inui M, Montagner M, Adorno M, Mamidi A, Morsut L, Soligo S, Tran U, Dupont S, et al. 2007. MicroRNA control of Nodal signalling. Nature 449: $183-188$.

Massague J, Seoane J, Wotton D. 2005. Smad transcription factors. Genes Dev 19: 2783-2810.

Mavrakis KJ, Andrew RL, Lee KL, Petropoulou C, Dixon JE, Navaratnam N, Norris DP, Episkopou V. 2007. Arkadia enhances Nodal/TGF- $\beta$ signaling by coupling phospho-Smad $2 / 3$ activity and turnover. PLoS Biol 5: e67.

McDowell N, Zorn AM, Crease DJ, Gurdon JB. 1997. Activin has direct long-range signalling activity and can form a concentration gradient by diffusion. Curr Biol 7: 671-681.

Meinhardt H, Gierer A. 2000. Pattern formation by local self-activation and lateral inhibition. Bioessays 22: $753-760$.

Meno C, Gritsman K, Ohishi S, Ohfuji Y, Heckscher E, Mochida K, Shimono A, Kondoh H, Talbot WS, Robertson EJ, et al. 1999. Mouse Lefty2 and zebrafish antivin are feedback inhibitors of nodal signaling during vertebrate gastrulation. Mol Cell 4: 287-298.

Meno C, Saijoh Y, Fujii H, Ikeda M, Yokoyama T, Yokoyama M, Toyoda Y, Hamada H. 1996. Left-right asymmetric expression of the TGF $\beta$-family member lefty in mouse embryos. Nature 381: 151-155.

Meno C, Shimono A, Saijoh Y, Yashiro K, Mochida K, Ohishi S, Noji S, Kondoh H, Hamada H. 1998. lefty-1 is required for left-right determination as a regulator of lefty-2 and nodal. Cell 94: 287-297.

Meno C, Takeuchi J, Sakuma R, Koshiba-Takeuchi K, Ohishi S, Saijoh Y, Miyazaki J, ten Dijke P, Ogura T, Hamada H. 2001. Diffusion of nodal signaling activity in the absence of the feedback inhibitor Lefty2. Dev Cell 1: 127-138.

Minchiotti G. 2005. Nodal-dependant Cripto signaling in ES cells: From stem cells to tumor biology. Oncogene 24: $5668-5675$.

Mir A, Kofron M, Zorn AM, Bajzer M, Haque M, Heasman J, Wylie CC. 2007. FoxIle activates ectoderm formation and controls cell position in the Xenopus blastula. Development 134: 779-788.

Mishima Y, Giraldez AJ, Takeda Y, Fujiwara T, Sakamoto H, Schier AF, Inoue K. 2006. Differential regulation of germline mRNAs in soma and germ cells by zebrafish miR-430. Curr Biol 16: 2135-2142.

Morgan TH. 1901. Regeneration. Columbia University Biological Series MacMillan \& Co., Ltd.

Nagano Y, Mavrakis KJ, Lee KL, Fujii T, Koinuma D, Sase H, Yuki K, Isogaya K, Saitoh M, Imamura T, et al. 2007. Arkadia induces degradation of $\mathrm{SnoN}$ and c-Ski to enhance transforming growth factor- $\beta$ signaling. J Biol Chem 282: 20492-20501. 


\section{A.F. Schier}

Nakamura T, Mine N, Nakaguchi E, Mochizuki A, Yamamoto M, Yashiro K, Meno C, Hamada H. 2006. Generation of robust left-right asymmetry in the mouse embryo requires a self-enhancement and lateralinhibition system. Dev Cell 11: 495-504.

Nicolas FJ, De Bosscher K, Schmierer B, Hill CS. 2004. Analysis of Smad nucleocytoplasmic shuttling in living cells. J Cell Sci 117: 4113-4125.

Niederlander C, Walsh JJ, Episkopou V, Jones CM. 2001. Arkadia enhances nodal-related signalling to induce mesendoderm. Nature 410: 830-834.

Nonaka S, Shiratori H, Saijoh Y, Hamada H. 2002. Determination of left-right patterning of the mouse embryo by artificial nodal flow. Nature 418: 96-99.

Nonaka S, Tanaka Y, Okada Y, Takeda S, Harada A, Kanai Y, Kido M, Hirokawa N. 1998. Randomization of left-right asymmetry due to loss of nodal cilia generating leftward flow of extraembryonic fluid in mice lacking KIF3B motor protein. Cell 95: 829-837.

Norris DP, Robertson EJ. 1999. Asymmetric and nodespecific nodal expression patterns are controlled by two distinct cis-acting regulatory elements. Genes Dev 13: $1575-1588$.

Norris DP, Brennan J, Bikoff EK, Robertson EJ. 2002. The Foxh1-dependent autoregulatory enhancer controls the level of Nodal signals in the mouse embryo. Development 129: 3455-3468.

Oki S, Hashimoto R, Okui Y, Shen MM, Mekada E, Otani H, Saijoh Y, Hamada H. 2007. Sulfated glycosaminoglycans are necessary for Nodal signal transmission from the node to the left lateral plate in the mouse embryo. Development 134: 3893-3904.

Onuma Y, Yeo CY, Whitman M. 2006. XCR2, one of three Xenopus EGF-CFC genes, has a distinct role in the regulation of left-right patterning. Development 133: 237-250.

Osada SI, Saijoh Y, Frisch A, Yeo CY, Adachi H, Watanabe M, Whitman M, Hamada H, Wright CV. 2000. Activin/ nodal responsiveness and asymmetric expression of a Xenopus nodal-related gene converge on a FASTregulated module in intron 1. Development 127: 2503-2514.

Parisi S, D’Andrea D, Lago CT, Adamson ED, Persico MG, Minchiotti G. 2003. Nodal-dependent Cripto signaling promotes cardiomyogenesis and redirects the neural fate of embryonic stem cells. J Cell Biol 163: 303-314.

Perea-Gomez A, Vella FD, Shawlot W, Oulad-Abdelghani M, Chazaud C, Meno C, Pfister V, Chen L, Robertson E, Hamada H, et al. 2002. Nodal antagonists in the anterior visceral endoderm prevent the formation of multiple primitive streaks. Dev Cell 3: 745-756.

Pfendler KC, Catuar CS, Meneses JJ, Pedersen RA. 2005. Overexpression of Nodal promotes differentiation of mouse embryonic stem cells into mesoderm and endoderm at the expense of neuroectoderm formation. Stem Cells Dev 14: 162-172.

Piccolo S, Agius E, Leyns L, Bhattacharyya S, Grunz H, Bouwmeester T, De Robertis EM. 1999. The head inducer Cerberus is a multifunctional antagonist of Nodal, BMP and Wnt signals. Nature 397: 707-710.

Pogoda HM, Solnica-Krezel L, Driever W, Meyer D. 2000. The zebrafish forkhead transcription factor FoxH1/
Fast1 is a modulator of nodal signaling required for organizer formation. Curr Biol 10: 1041-1049.

Rankin CT, Bunton T, Lawler AM, Lee SJ. 2000. Regulation of left-right patterning in mice by growth/differentiation factor-1. Nat Genet 24: 262-265.

Rebagliati MR, Toyama R, Fricke C, Haffter P, Dawid IB. 1998a. Zebrafish nodal-related genes are implicated in axial patterning and establishing left-right asymmetry. Dev Biol 199: 261-272.

Rebagliati MR, Toyama R, Haffter P, Dawid IB. 1998b. cyclops encodes a nodal-related factor involved in midline signaling. Proc Natl Acad Sci 95: 9932-9937.

Reilly KM, Melton DA. 1996. Short-range signaling by candidate morphogens of the TGF $\beta$ family and evidence for a relay mechanism of induction. Cell 86: 743-754.

Reissmann E, Jornvall H, Blokzijl A, Andersson O, Chang C, Minchiotti G, Persico MG, Ibanez CF, Brivanlou AH. 2001. The orphan receptor ALK7 and the Activin receptor ALK4 mediate signaling by Nodal proteins during vertebrate development. Genes Dev 15: 2010-2022.

Rosa A, Spagnoli FM, Brivanlou AH. 2009. The miR-430/ 427/302 Family Controls Mesendodermal Fate Specification via Species-Specific Target Selection. Developmental Cell 16: 517-527.

Ross S, Hill CS. 2008. How the Smads regulate transcription. Int J Biochem Cell Biol 40: 383-408.

Roussigne M, Bianco IH, Wilson SW, Blader P. 2009. Nodal signalling imposes left-right asymmetry upon neurogenesis in the habenular nuclei. Development 136: 1549-1557.

Saijoh Y, Adachi H, Sakuma R, Yeo CY, Yashiro K, Watanabe M, Hashiguchi H, Mochida K, Ohishi S, Kawabata M, et al. 2000. Left-right asymmetric expression of lefty 2 and nodal is induced by a signaling pathway that includes the transcription factor FAST2. Mol Cell 5: 35-47.

Saijoh Y, Oki S, Ohishi S, Hamada H. 2003. Left-right patterning of the mouse lateral plate requires nodal produced in the node. Dev Biol 256: 160-172.

Saijoh Y, Oki S, Tanaka C, Nakamura T, Adachi H, Yan YT, Shen MM, Hamada H. 2005. Two nodal-responsive enhancers control left-right asymmetric expression of Nodal. Dev Dyn 232: 1031-1036.

Sampath K, Rubinstein AL, Cheng AM, Liang JO, Fekany K, Solnica-Krezel L, Korzh V, Halpern ME, Wright CV. 1998. Induction of the zebrafish ventral brain and floorplate requires cyclops/nodal signalling. Nature 395: 185-189.

Sasai N, Yakura R, Kamiya D, Nakazawa Y, Sasai Y. 2008. Ectodermal factor restricts mesoderm differentiation by inhibiting 53. Cell 133: 878-890.

Schier AF. 2003. Nodal signaling in vertebrate development. Anпи Rev Cell Dev Biol 19: 589-621.

Schier AF, Shen MM. 2000. Nodal signalling in vertebrate development. Nature 403: 385-389.

Schier AF, Talbot WS. 2005. Molecular genetics of axis formation in zebrafish. Annu Rev Genet 39: 561-613.

Schier AF, Neuhauss SC, Helde KA, Talbot WS, Driever W. 1997. The one-eyed pinhead gene functions in mesoderm and endoderm formation in zebrafish and interacts with no tail. Development 124: 327-342.

Schmierer B, Hill CS. 2005. Kinetic analysis of Smad nucleocytoplasmic shuttling reveals a mechanism for 
transforming growth factor $\beta$-dependent nuclear accumulation of Smads. Mol Cell Biol 25: 9845-9858.

Schmierer B, Tournier AL, Bates PA, Hill CS. 2008. Mathematical modeling identifies Smad nucleocytoplasmic shuttling as a dynamic signal-interpreting system. Proc Natl Acad Sci 105: 6608-6613.

Shen MM. 2007. Nodal signaling: Developmental roles and regulation. Development 134: 1023-1034.

Shen MM, Schier AF. 2000. The EGF-CFC gene family in vertebrate development. Trends Genet 16: 303-309.

Shen MM, Wang H, Leder P. 1997. A differential display strategy identifies Cryptic, a novel EGF-related gene expressed in the axial and lateral mesoderm during mouse gastrulation. Development 124: 429-442.

Shiratori H, Hamada H. 2006. The left-right axis in the mouse: From origin to morphology. Development 133: 2095-2104.

Shiratori H, Sakuma R, Watanabe M, Hashiguchi H, Mochida K, Sakai Y, Nishino J, Saijoh Y, Whitman M, Hamada H. 2001. Two-step regulation of left-right asymmetric expression of Pitx2: Initiation by nodal signaling and maintenance by $\mathrm{Nkx} 2$. Mol Cell 7: 137-149.

Shiratori H, Yashiro K, Shen MM, Hamada H. 2006. Conserved regulation and role of Pitx2 in situs-specific morphogenesis of visceral organs. Development 133: 3015-3025.

Silva AC, Filipe M, Kuerner KM, Steinbeisser H, Belo JA. 2003. Endogenous Cerberus activity is required for anterior head specification in Xenopus. Development 130: $4943-4953$.

Sirotkin HI, Gates MA, Kelly PD, Schier AF, Talbot WS, 2000. Fast1 is required for the development of dorsal axial structures in zebrafish. Curr Biol 10: 1051-1054.

Smith JR, Vallier L, Lupo G, Alexander M, Harris WA, Pedersen RA. 2008. Inhibition of Activin/Nodal signaling promotes specification of human embryonic stem cells into neuroectoderm. Dev Biol 313: 107-117.

Solnica-Krezel L. 2005. Conserved patterns of cell movements during vertebrate gastrulation. Curr Biol 15: 213-228.

Stern CD. 2004. Gastrulation: From cells to embryo. Cold Spring Harbor Laboratory Press, New York, 2004.

Suri C, Haremaki T, Weinstein DC. 2005. Xema, a foxi-class gene expressed in the gastrula stage Xenopus ectoderm, is required for the suppression of mesendoderm. Development 132: 2733-2742.

Takahashi S, Yokota C, Takano K, Tanegashima K, Onuma Y, Goto J, Asashima M. 2000. Two novel nodal-related genes initiate early inductive events in Xenopus Nieuwkoop center. Development 127: 5319-5329.

Takebayashi-Suzuki K, Funami J, Tokumori D, Saito A, Watabe T, Miyazono K, Kanda A, Suzuki A. 2003. Interplay between the tumor suppressor p53 and TGF $\beta$ signaling shapes embryonic body axes in Xenopus. Development 130: 3929-3939.

Takenaga M, Fukumoto M, Hori Y. 2007. Regulated Nodal signaling promotes differentiation of the definitive endoderm and mesoderm from ES cells. J Cell Sci 120: 2078-2090.
Tam PP, Loebel DA. 2007. Gene function in mouse embryogenesis: Get set for gastrulation. Nat Rev Genet 8: $368-381$.

Tanaka C, Sakuma R, Nakamura T, Hamada H, Saijoh Y. 2007. Long-range action of Nodal requires interaction with GDF1. Genes Dev 21: 3272-3282.

Tavares AT, Andrade S, Silva AC, Belo JA. 2007. Cerberus is a feedback inhibitor of Nodal asymmetric signaling in the chick embryo. Development 134: 2051-2060.

Thisse C, Thisse B. 1999. Antivin, a novel and divergent member of the TGF $\beta$ superfamily, negatively regulates mesoderm induction. Development 126: 229-240.

Thisse B, Wright CV, Thisse C. 2000. Activin- and Nodal-related factors control antero-posterior patterning of the zebrafish embryo. Nature 403: 425-428.

Thomsen GH, Melton DA. 1993. Processed Vg1 protein is an axial mesoderm inducer in Xenopus. Cell 74: 433-441.

Tian J, Andree B, Jones CM, Sampath K. 2008. The prodomain of the zebrafish Nodal-related protein Cyclops regulates its signaling activities. Development 135: 2649-2658.

Toyama R, O'Connell ML, Wright CV, Kuehn MR, Dawid IB. 1995. Nodal induces ectopic goosecoid and $\lim 1$ expression and axis duplication in zebrafish. Development 121: 383-391.

Turing AM. 1952. The chemical basis of morphogenesis. Philos Trans R Soc Lond B Biol Sci B237: 37-72.

Vallier L, Reynolds D, Pedersen RA. 2004. Nodal inhibits differentiation of human embryonic stem cells along the neuroectodermal default pathway. Dev Biol 275: 403-421.

Vallier L, Alexander M, Pedersen RA. 2005. Activin/Nodal and FGF pathways cooperate to maintain pluripotency of human embryonic stem cells. J Cell Sci 118: 4495-4509.

Vallier L, Mendjan S, Brown S, Chng Z, Teo A, Smithers LE, Trotter MW, Cho CH, Martinez A, Rugg-Gunn P, et al. 2009. Activin/Nodal signalling maintains pluripotency by controlling Nanog expression. Development 136: $1339-1349$.

Vincent SD, Dunn NR, Hayashi S, Norris DP, Robertson EJ. 2003. Cell fate decisions within the mouse organizer are governed by graded Nodal signals. Genes Dev 17: $1646-1662$.

Vincent SD, Norris DP, Le Good JA, Constam DB, Robertson EJ. 2004. Asymmetric Nodal expression in the mouse is governed by the combinatorial activities of two distinct regulatory elements. Mech Dev 121: 1403-1415.

Williams PH, Hagemann A, Gonzalez-Gaitan M, Smith JC. 2004. Visualizing long-range movement of the morphogen Xnr2 in the Xenopus embryo. Curr Biol 14: 1916-1923.

Wu MY, Hill CS. 2009. Tgf- $\beta$ superfamily signaling in embryonic development and homeostasis. Dev Cell 16: 329-343.

Xu L, Kang Y, Col S, Massague J. 2002. Smad2 nucleocytoplasmic shuttling by nucleoporins CAN/Nup214 and Nup153 feeds TGF $\beta$ signaling complexes in the cytoplasm and nucleus. Mol Cell 10: 271-282.

Yamamoto M, Meno C, Sakai Y, Shiratori H, Mochida K, Ikawa Y, Saijoh Y, Hamada H. 2001. The transcription 


\section{A.F. Schier}

factor FoxH1 (FAST) mediates Nodal signaling during anterior-posterior patterning and node formation in the mouse. Genes Dev 15: 1242-1256.

Yamamoto M, Mine N, Mochida K, Sakai Y, Saijoh Y, Meno C, Hamada H. 2003. Nodal signaling induces the midline barrier by activating Nodal expression in the lateral plate. Development 130: 1795-1804.

Yamamoto M, Saijoh Y, Perea-Gomez A, Shawlot W, Behringer RR, Ang SL, Hamada H, Meno C. 2004 Nodal antagonists regulate formation of the anteroposterior axis of the mouse embryo. Nature 428: 387-392.

Yan YT, Gritsman K, Ding J, Burdine RD, Corrales JD, Price SM, Talbot WS, Schier AF, Shen MM. 1999. Conserved requirement for EGF-CFC genes in vertebrate left-right axis formation. Genes Dev 13: 2527-2537.

Yan YT, Liu JJ, Luo YEC, Haltiwanger RS, Abate-Shen C, Shen MM. 2002. Dual roles of Cripto as a ligand and coreceptor in the nodal signaling pathway. Mol Cell Biol 22: 4439-4449.

Yashiro K, Shiratori H, Hamada H. 2007. Haemodynamics determined by a genetic programme govern asymmetric development of the aortic arch. Nature 450: 285-288.
Yeo C, Whitman M. 2001. Nodal signals to Smads through Cripto-dependent and Cripto-independent mechanisms. Mol Cell 7: 949-957.

Yun CH, Choi SC, Park E, Kim SJ, Chung AS, Lee HK, Lee HJ, Han JK. 2007. Negative regulation of Activin/Nodal signaling by SRF during Хеnopus gastrulation. Development 134: 769-777.

Zhang C, Klymkowsky MW. 2007. The Sox axis, Nodal signaling, and germ layer specification. Differentiation 75: 536-545.

Zhang J, Talbot WS, Schier AF. 1998. Positional cloning identifies zebrafish one-eyed pinhead as a permissive EGF-related ligand required during gastrulation. Cell 92: $241-251$.

Zhang L, Zhou H, Su Y, Sun Z, Zhang H, Zhang L, Zhang Y, Ning Y, Chen YG, Meng A. 2004. Zebrafish Dpr2 inhibits mesoderm induction by promoting degradation of nodal receptors. Science 306: 114-117.

Zhou X, Sasaki H, Lowe L, Hogan BL, Kuehn MR. 1993. Nodal is a novel TGF- $\beta$-like gene expressed in the mouse node during gastrulation. Nature 361: $543-547$. 


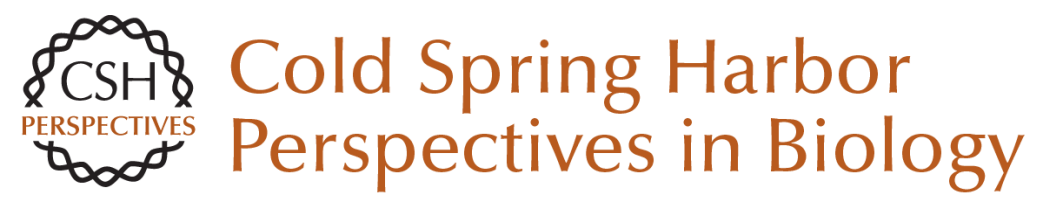

\section{Nodal Morphogens}

Alexander F. Schier

Cold Spring Harb Perspect Biol 2009; doi: 10.1101/cshperspect.a003459 originally published online August 26, 2009

Subject Collection Generation and Interpretation of Morphogen Gradients

Regulation of Organ Growth by Morphogen Gradients

Gerald Schwank and Konrad Basler

Signaling Gradients during Paraxial Mesoderm

Development Alexander Aulehla and Olivier Pourquié

Morphogen Gradient Formation

Ortrud Wartlick, Anna Kicheva and Marcos

González-Gaitán

Nodal Morphogens

Alexander F. Schier

Gradients and the Specification of Planar Polarity

in the Insect Cuticle

David Strutt

Vertebrate Limb Development: Moving from

Classical Morphogen Gradients to an Integrated

4-Dimensional Patterning System Jean-Denis Bénazet and Rolf Zeller

Establishing and Interpreting Graded Sonic

Hedgehog Signaling during Vertebrate Neural

Tube Patterning: The Role of Negative Feedback Vanessa Ribes and James Briscoe

Systems Biology of the Self-regulating

Morphogenetic Gradient of the Xenopus Gastrula Jean-Louis Plouhinec and E. M. De Robertis
Gradients in Planarian Regeneration and Homeostasis

Teresa Adell, Francesc Cebrià and Emili Saló

Shaping Morphogen Gradients by Proteoglycans Dong Yan and Xinhua Lin

Forming Patterns in Development without Morphogen Gradients: Scattered Differentiation and Sorting Out

Robert R. Kay and Christopher R.L. Thompson

Robust Generation and Decoding of Morphogen Gradients

Naama Barkai and Ben-Zion Shilo

Models for the Generation and Interpretation of

Gradients

Hans Meinhardt

Graded Dorsal and Differential Gene Regulation in the Drosophila Embryo

Gregory T. Reeves and Angelike Stathopoulos

Chemical Gradients and Chemotropism in Yeast Robert A. Arkowitz

Gradients in the Brain: The Control of the Development of Form and Function in the Cerebral Cortex

Stephen N. Sansom and Frederick J. Livesey

For additional articles in this collection, see http://cshperspectives.cshlp.org/cgi/collection/

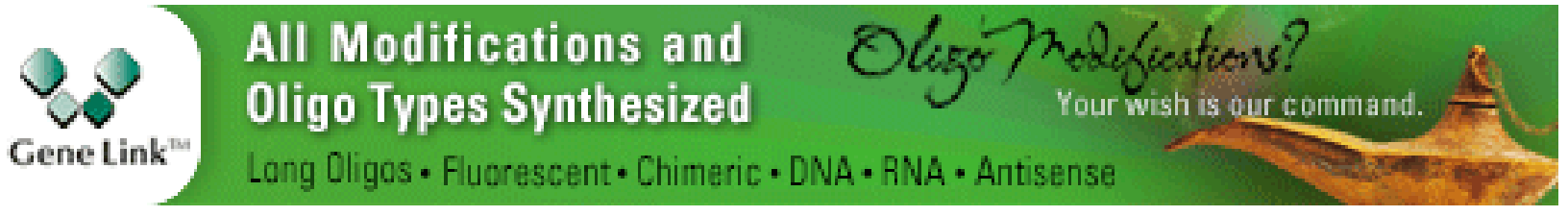

Copyright @ 2009 Cold Spring Harbor Laboratory Press; all rights reserved 
For additional articles in this collection, see http://cshperspectives.cshlp.org/cgi/collection/

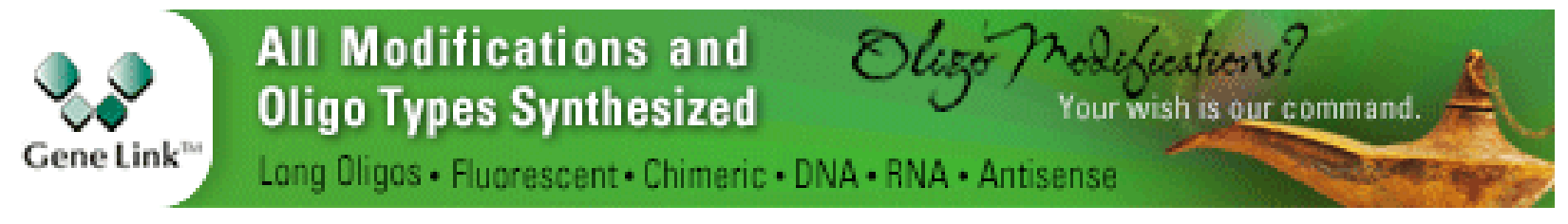

Copyright @ 2009 Cold Spring Harbor Laboratory Press; all rights reserved 